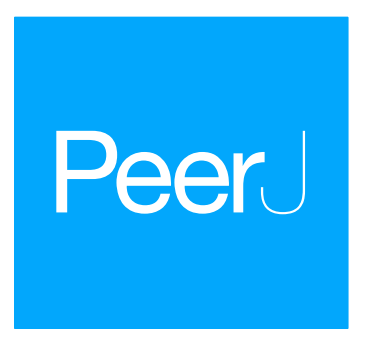

Submitted 1 December 2017 Accepted 15 February 2018 Published 5 March 2018

Corresponding author Alberto Peña-Rodríguez, apena@cibnor.mx

Academic editor

Meenakshisundaram Swaminathan

Additional Information and Declarations can be found on page 10

DOI 10.7717/peerj.4459

Copyright

2018 Elizondo-González et al.

Distributed under

Creative Commons CC-BY 4.0

OPEN ACCESS

\section{Use of seaweed Ulva lactuca for water bioremediation and as feed additive for white shrimp Litopenaeus vannamei}

Regina Elizondo-González, Eduardo Quiroz-Guzmán, Cristina Escobedo-Fregoso, Paola Magallón-Servín and Alberto Peña-Rodríguez

CONACYT-Centro de Investigaciones Biológicas del Noroeste, La Paz, Baja California Sur, México

\section{ABSTRACT}

Two experimental feeding trials were conducted during four weeks to evaluate the use of Ulva lactuca in shrimp culture: (1) for wastewater bioremediation, and (2) using different inclusion levels of U. lactuca meal in shrimp feed. In feeding trial 1, shrimp reared under seaweed U. lactuca water exchange in a re-circulation system (SWE) resulted in similar growth and feed utilization as shrimp reared with clean water exchange (CWE). Shrimp under no water exchange (NWE) resulted in significant lower growth and higher feed conversion rate (FCR) compared to the other treatments $(p<$ $0.05)$. Nitrogen compounds and phosphate in water from SWE and CWE treatments did not present significant differences during the experimental trial $(p>0.05)$. In feeding trial 2, U. lactuca biomass produced by wastewater bioremediation in SWE treatment were dried and ground to formulate diets containing $0,1,2$, and $3 \% U$. lactuca meal (0UL, 1UL, 2UL, and 3UL). Shrimp fed the $3 \mathrm{UL}$ diet resulted in a significant $(p<0.05)$ improvement of growth and FCR, and enhanced whole shrimp lipid and carotenoid content by 30 and $60 \%$, respectively, compared to control diet. Seaweed $U$. lactuca is suggested as a desirable species for wastewater bioremediation in integrated aquaculture systems, and its meal as a good feed additive for farmed shrimp.

Subjects Aquaculture, Fisheries and Fish Science, Environmental Contamination and Remediation

Keywords Feed additive, Seaweed, Shrimp, Water quality

\section{INTRODUCTION}

In the last decades, aquaculture has been one of the fastest growing industries of food production. By 2015, farmed shrimp represented an estimate global production of 4.8 million metric tons, with a value of US $\$ 24.96$ billion (FAO, 2017). Some of the challenges for this growing activity are the reduction of coastal water pollution impact (Herbeck et al., 2013) and the search for non-conventional ingredients to produce high quality feeds (Little, Newton \& Beveridge, 2016). In the case of seaweeds produced by aquaculture, it has been estimated by 2015 a worldwide production of 28.5 million metric tons valued in US $\$ 4.46$ billion (FAO, 2017). For Ulva lactuca seaweed, research interest has increased due to their rapid vegetative growth in the presence of high nutrient levels and has been adapted to culture in tanks (DeBusk, Blakeslee \& Ryther, 1986), with various industrial applications including human and animal nutrition (Ortiz et al., 2006; Yaich et al., 2011). 
The use of seaweeds in integrated multi-trophic aquaculture (IMTA) has been proposed as an alternative for environmental-sustainable expansion of aquaculture, serving as primary food source and also for water bioremediation due to their high capability of removing inorganic nutrients from wastewater (Neori et al., 2004; Neori, 2008; Fleurence et al., 2012). Benefits of integrated aquaculture of shrimp and green seaweeds has been documented for Ulva clathrata that showed high efficiency in removing the inorganic nutrients from water effluents (Copertino, Tormena \& Seeliger, 2009), in addition as an improvement of feed utilization in white shrimp Litopenaeus vannamei (Cruz-Suárez et al., 2010) and in brown shrimp Farfantepenaeus californiensis (Peña Rodríguez et al., 2016; Peña Rodríguez et al., 2017). U. lactuca improved water quality when cultured with western king prawn Penaeus latisulcatus (Van Khoi \& Fotedar, 2011) and with L. vannamei (Brito et al., 2014); Caulerpa sertularioides presence resulted in F. californiensis growth enhancement (Portillo-Clark et al., 2012).

Seaweeds are an excellent source of protein, carotenoids, minerals, polysaccharides, and vitamins making their utilization as feed additives attractive (Kumar et al., 2011; Peña Rodríguez et al., 2011; Syad, Shunmugiah \& Kasi, 2013). Some seaweeds have been suggested as a partial feed substitute (Marinho-Soriano et al., 2007) for shrimp diet, and considered a good source of protein (Da Silva \& Barbosa, 2009), which represents the most expensive fraction of feed cost. In some cases, shrimp composition is modified when fed seaweeds, these changes may include lipid content and carotenoids (Cruz-Suárez et al., 2010; Subhra Bikash, 2015), or total cholesterol (Casas-Valdez et al., 2006). The optimal level of inclusion of seaweed meal in shrimp feed varies among seaweed species, but, in most cases, studies have found benefits when included not higher than 5\% (Cruz-Suárez et al., 2009; Rodríguez-González et al., 2014; Cárdenas et al., 2015; Yu et al., 2016; Schleder et al., 2017).

Despite some studies explore the use seaweeds for water bioremediation, there is no reports of the use of $U$. lactuca produced under these conditions as a feed ingredient for shrimp. The aim of the present work was to evaluate shrimp growth and water quality of an integrated culture system with $U$. lactuca and, on the other side, the effect of $U$. lactuca meal as feed additive at different inclusion levels on shrimp performance, lipid and carotenoid content.

\section{MATERIALS AND METHODS Collection and maintenance of seaweed}

Seaweed U. lactuca was collected from the La Paz bay in Baja California Sur, Mexico (Collection permit Conapesca \#PRMN/DGOPA-019/2015). The U. lactuca was washed with sterilized marine water to remove epiphytes, then placed in laboratory conditions, in 5-L marine water tanks, at $25^{\circ} \mathrm{C}$, with a photoperiod of $12 \mathrm{~h}: 12 \mathrm{~h}$ light:dark with fluorescent light tubes of $75 \mathrm{~W}$, and using Provasoli medium at a constant concentration of $0.5 \mathrm{ppm}$ of nitrogen in water. The $U$. lactuca was kept under laboratory conditions during two weeks prior to the feeding trial. 


\section{Feeding trials}

For the first experimental trial, three different treatments during 28 days were evaluated: clean water exchange (CWE), seaweed U. lactuca water exchange (SWE), and no water exchange (NWE). The CWE treatment consisted in 50\% daily exchange of clean water using marine water pumped from an open water intake from La Paz bay, filtered up to $1-\mu \mathrm{m}$ mesh and sterilized by UV light. For the SWE treatment, one tank of $50 \mathrm{~L}$ was placed with $50 \mathrm{~g}$ of $U$. lactuca next to a shrimp tank, making a 50\% daily water exchange in a re-circulation system (using a transitory tank to make the exchange) between shrimp and U. lactuca tanks, without new clean water input. Each U. lactuca tank was provided with artificial light (cool-white fluorescent lamps $70 \mathrm{~W}$; Osram) with photoperiod of 12h:12 h light:dark. The U. lactuca was partially harvested every week to maintain $50 \mathrm{~g}$ in each tank. The harvested $U$. lactuca was washed with distilled water, dried in a forced-air oven at $50{ }^{\circ} \mathrm{C}$ for $4 \mathrm{~h}$, and stored at $4{ }^{\circ} \mathrm{C}$ until use for feeding trial 2 . In the case of NWE treatment, only $5 \%$ of clean water was recovered in each tank per week due to evaporation. All treatments were evaluated in triplicate, and each replicate consisted of a 50-L fiberglass tank provided with aeration and temperature control containing $10 \mathrm{~L}$. vannamei shrimp (initial weight $0.30 \pm 0.05 \mathrm{~g}$ ) obtained from a commercial hatchery (Acuacultura Mahr, S.A. de C.V.) and previously acclimated to laboratory conditions $\left(28^{\circ} \mathrm{C}\right.$ and $35 \%$ salinity). Shrimp from all treatments were fed with a control feed of $34 \%$ crude protein and $8 \%$ lipids (see Table 1 , treatment $0 \mathrm{UL}$ ), with an initial rate of $10 \%$ biomass divided in two rations distributed at 9:00 and 15:00 h. After second day, the feeding rate was ad libitum by adjusting each tank according to consumed feed. The feed was manufactured in the Aquaculture nutrition laboratory at CIBNOR. All dry ingredients $(\geq 250 \mu \mathrm{m})$ were mixed first, then oil-based ingredients and water were added and mixed again to obtain a homogenous mixture, and passed through a $2-\mathrm{mm}$ die in a meat grinder. The pellets were dried in a forced-air oven at $45^{\circ} \mathrm{C}$ for $12 \mathrm{~h}$, and stored at $4{ }^{\circ} \mathrm{C}$ until feeding time.

During the experimental period, water temperature, $\mathrm{pH}$ and oxygen were monitored daily with a multiparameter YSI 556 (YSI Incorporated, Yellow Springs, OH, USA). The total ammonia, nitrites, nitrates, and phosphate were measured every four days by spectrophotometric methods according to the manufacturer's specification (LYSA, Mexico). At the end of the experimental period, shrimp performance was measured in terms of final weight, weight gain, specific growth rate (SGR), feed conversion ratio (FCR), feed consumption, and survival.

For the second experiment, a 28 day feeding trial was performed to evaluate the U. lactuca meal produced by water bioremediation. Based on the control diet of experiment 1 , three more diets were produced including 1,2 , and $3 \%$ levels of the U. lactuca meal (in substitution of the same proportion of wheat meal) (see Table 1). All experimental $U$. lactuca feeds were produced as described previously as in the control feed. Each treatment was evaluated in triplicate as described in experiment 1, using shrimps with an initial average weight of $0.59 \pm 0.09 \mathrm{~g}$. Feeding strategy was conducted as in the previous trial. At the end of the experimental period, five complete shrimps and five shrimps separated in cephalothorax (head) and tail from each treatment were lyophilized for total lipid and carotenoid analysis. Total lipid content was performed according to 
Table 1 Ingredients, proximate composition, and gross energy of experimental diets and Ulva lactuca meal.

\begin{tabular}{|c|c|c|c|c|c|}
\hline & OUL & $1 \mathrm{UL}$ & $2 U L$ & $3 U L$ & U. lactuca \\
\hline \multicolumn{6}{|l|}{ Ingredients } \\
\hline Fish meal $^{\mathrm{a}}$ & 240 & 240 & 240 & 240 & \\
\hline Soybean meal ${ }^{\mathrm{b}}$ & 230 & 230 & 230 & 230 & \\
\hline Wheat meal ${ }^{c}$ & 401 & 391 & 381 & 371 & \\
\hline Soy lecithin & 41 & 41 & 41 & 41 & \\
\hline Corn gluten $^{e}$ & 30 & 30 & 30 & 30 & \\
\hline Fish oil $^{\mathrm{a}}$ & 24 & 24 & 24 & 24 & \\
\hline Vitamin premix & 18 & 18 & 18 & 18 & \\
\hline Grenetin $^{\mathrm{g}}$ & 10 & 10 & 10 & 10 & \\
\hline Mineral premix ${ }^{\mathrm{h}}$ & 5 & 5 & 5 & 5 & \\
\hline Vitamin $\mathrm{C}^{\mathrm{i}}$ & 1 & 1 & 1 & 1 & \\
\hline Ulva lactuca meal & 0 & 10 & 20 & 30 & \\
\hline \multicolumn{6}{|l|}{$\begin{array}{l}\text { Proximate composition } \\
\text { (g } 100 \mathrm{~g}^{-1} \text { dry matter) }\end{array}$} \\
\hline Moisture & $8.3 \pm 0.1$ & $8.2 \pm 0.1$ & $8.7 \pm 0.2$ & $8.5 \pm 0.1$ & $8.7 \pm 0.1$ \\
\hline Protein & $33.9 \pm 0.24$ & $33.9 \pm 0.06$ & $33.7 \pm 0.10$ & $33.5 \pm 0.08$ & $15.5 \pm 0.1$ \\
\hline Lipids & $7.9 \pm 0.08$ & $7.9 \pm 0.03$ & $7.9 \pm 0.06$ & $7.9 \pm 0.12$ & $0.3 \pm 0.01$ \\
\hline Crude Fiber & $0.87 \pm 0.01$ & $0.86 \pm 0.06$ & $0.86 \pm 0.03$ & $0.87 \pm 0.06$ & $3.3 \pm 0.1$ \\
\hline Ash & $6.6 \pm 0.03$ & $6.9 \pm 0.03$ & $7.3 \pm 0.01$ & $7.7 \pm 0.03$ & $36.5 \pm 0.1$ \\
\hline NFE & 50.6 & 50.3 & 50.2 & 50.0 & 44.5 \\
\hline Gross energy $\left(\mathrm{MJ} \mathrm{kg}^{-1}\right)$ & $18.09 \pm 0.47$ & $17.93 \pm 0.22$ & $17.77 \pm 0.35$ & $17.60 \pm 0.28$ & $9.46 \pm 0.14$ \\
\hline
\end{tabular}

Notes.

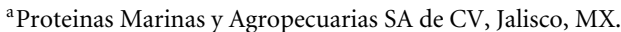

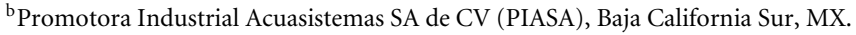

${ }^{\mathrm{c}}$ Molino San Cristobal, Sonora, MX.

${ }^{\mathrm{d} S u m i n i s t r o s ~ A Z, ~ B a j a ~ C a l i f o r n i a ~ S u r, ~ M X . ~}$

${ }^{\mathrm{e}}$ Agro Insumos Basicos, SA de CV, MX.

fVitamins: Vit. A, (20,000 UI/g) 90 mg/kg; Vit. B1, 9 mg/kg; Vit. B2, 54 mg $/ \mathrm{kg}$; Vit. B5, 90 mg/kg; Vit. B6, 18 mg/kg; Vit. B12, $0.04 \mathrm{mg} / \mathrm{kg}$; Vit. K3, $36 \mathrm{mg} / \mathrm{kg}$; Vit. D3, (850,000 UI/g) $144 \mathrm{mg} / \mathrm{kg}$; Vit. H, 1 mg/kg; folic acid, $3.24 \mathrm{mg} / \mathrm{kg}$; Inositol, $90 \mathrm{mg} / \mathrm{kg}$. Sigma aldrich, Missouri, US.

${ }^{g}$ Knox, Estado de Mexico, MX.

${ }^{h}$ Minerals: $\mathrm{CoCl}_{2}, 20 \mathrm{mg} / \mathrm{kg} ; \mathrm{H}_{2} \mathrm{MnO}_{5} \mathrm{~S}, 3.3 \mathrm{~g} / \mathrm{kg} ; \mathrm{H}_{14} \mathrm{O}_{11} \mathrm{SZn}, 66 \mathrm{~g} / \mathrm{kg} ; \mathrm{CuH}_{10} \mathrm{O}_{9} \mathrm{~S}, 1.3 \mathrm{~g} / \mathrm{kg} ; \mathrm{FeSO}_{4}, 20 \mathrm{~g} / \mathrm{kg} ; \mathrm{Na}_{2} \mathrm{SeO}_{3}, 50$ $\mathrm{mg} / \mathrm{kg} ; \mathrm{KI}, 330 \mathrm{mg} / \mathrm{kg}$. Sigma Aldrich, Missouri, US.

${ }^{i}$ Rovimix Stay C 35\%, DSM, Heerlen, NL.

Values of proximate composition are given as mean $\pm \mathrm{SD}$ of triplicate determinations.

Barnes \& Blackstock (1973) by using phosphosulphovanillin method and measured by spectrophotometry (Multiskan spectrum; Thermo Fisher, Vantaa, Finland) at $540 \mathrm{~nm}$. Total carotenoid content was analyzed according to Palacios et al. (1999), employing acetone:methanol (2:1) for extraction and measured by spectrophotometry at $495 \mathrm{~nm}$.

Water quality parameters were measured as described previously. Proximate analysis of all experiment feeds and U. lactuca was conducted according to AOAC (2005) methods, nitrogen free extract (NFE) was calculated through difference, and gross energy was measured with an adiabatic calorimeter. Total carotenoids from U. lactuca meal was analyzed as described for shrimp samples. The proximate composition of experimental feeds and $U$. lactuca meal are presented in Table 1. 


\begin{tabular}{|c|c|c|c|c|}
\hline & CWE & SWE & NWE & $P$ value \\
\hline Final weight (g) & $2.15 \pm 0.06^{\mathrm{b}}$ & $2.08 \pm 0.04^{\mathrm{b}}$ & $1.82 \pm 0.05^{\mathrm{a}}$ & 0.000 \\
\hline Weight gain (\%) & $613 \pm 19^{b}$ & $593 \pm 12^{\mathrm{b}}$ & $503 \pm 16^{\mathrm{a}}$ & 0.000 \\
\hline SGR $\left(\%\right.$ day $\left.^{-1}\right)$ & $7.02 \pm 0.10^{\mathrm{b}}$ & $6.91 \pm 0.06^{\mathrm{b}}$ & $6.42 \pm 0.10^{\mathrm{a}}$ & 0.000 \\
\hline FC (g) & $2.20 \pm 0.08$ & $2.11 \pm 0.02$ & $2.14 \pm 0.05$ & 0.214 \\
\hline FCR & $1.19 \pm 0.01^{\mathrm{a}}$ & $1.18 \pm 0.02^{\mathrm{a}}$ & $1.41 \pm 0.06^{\mathrm{b}}$ & 0.000 \\
\hline Survival (\%) & $90 \pm 10$ & $96 \pm 6$ & $83 \pm 6$ & 0.171 \\
\hline
\end{tabular}

Notes.

Values are given as mean \pm SD of triplicate determinations. Means with different superscripts in same row are significantly different $(p<0.05)$.

Weight gain (\%), (final weight-initial weight)/ initial weight $\times 100$; SGR $\left(\%\right.$ day $\left.^{-1}\right), 100(\ln$ (average final weight)-ln $($ average initial weight))/number of days; FC (g), pelleted feed consumed per shrimp; FCR, pelleted feed consumed (g)/wet weight gain (g); Survival (\%), final number of shrimp/ initial number of shrimp $\times 100$.

\section{Data analysis}

Data were analyzed for normality and homoscedasticity through Shapiro-Wilk and Levene's test, respectively. Results were reported as means \pm standard deviation (SD) and group means were compared using one-way analysis of variance (ANOVA) followed, if applicable, of a Tukey's multiple comparison test ( $95 \%$ confidence). All data were analyzed with the SPSS Statistics 17.0 software.

\section{RESULTS}

At the end of feeding trial 1, shrimp under daily clean water exchange (CWE) and daily seaweed $U$. lactuca water exchange (SWE) treatments resulted in significant higher $(p<0.05)$ final weight, weight gain, and SGR compared to shrimp with no water exchange (NWE) (Table 2). Feed consumption was similar among the treatments, nevertheless FCR observed in NWE treatment was significantly higher than the rest of the treatments $(p<0.05)$. Shrimp under NWE treatment showed a lower percentage of survival but not significantly different compared to the rest of treatments. At the end of the experimental period, water quality parameters were significantly different among treatments (Fig. 1). The NWE treatment resulted in significant increment $(p<0.05)$ of total ammonia nitrogen, nitrites, nitrates, and phosphate compared to treatments with water exchange, whereas the $\mathrm{pH}$ showed no significant differences among treatments. Removal of inorganic compounds in $U$. lactuca treated water was higher than $80 \%$ for nitrogenous compounds and $64 \%$ for phosphate compared to the treatment without water exchange. Total harvest of fresh $U$. lactuca, under the experimental conditions, was $225 \pm 25 \mathrm{~g}$ per tank, with a specific growth rate of $5.37 \pm 0.41\left(\%\right.$ day $\left.^{-1}\right)$. After drying, U. lactuca meal resulted in a $15.5 \%$ of crude protein and $36.5 \%$ ash (Table 1), which was used to prepare experimental feeds for feeding trial 2.

In feeding trial 2, experimental feeds did no show differences in proximal composition except for ash content in feed containing $3 \%$ of $U$. lactuca meal (3UL), which resulted $1.1 \%$ higher compared to the control feed (0UL) as expected. Total carotenoids in U. lactuca 

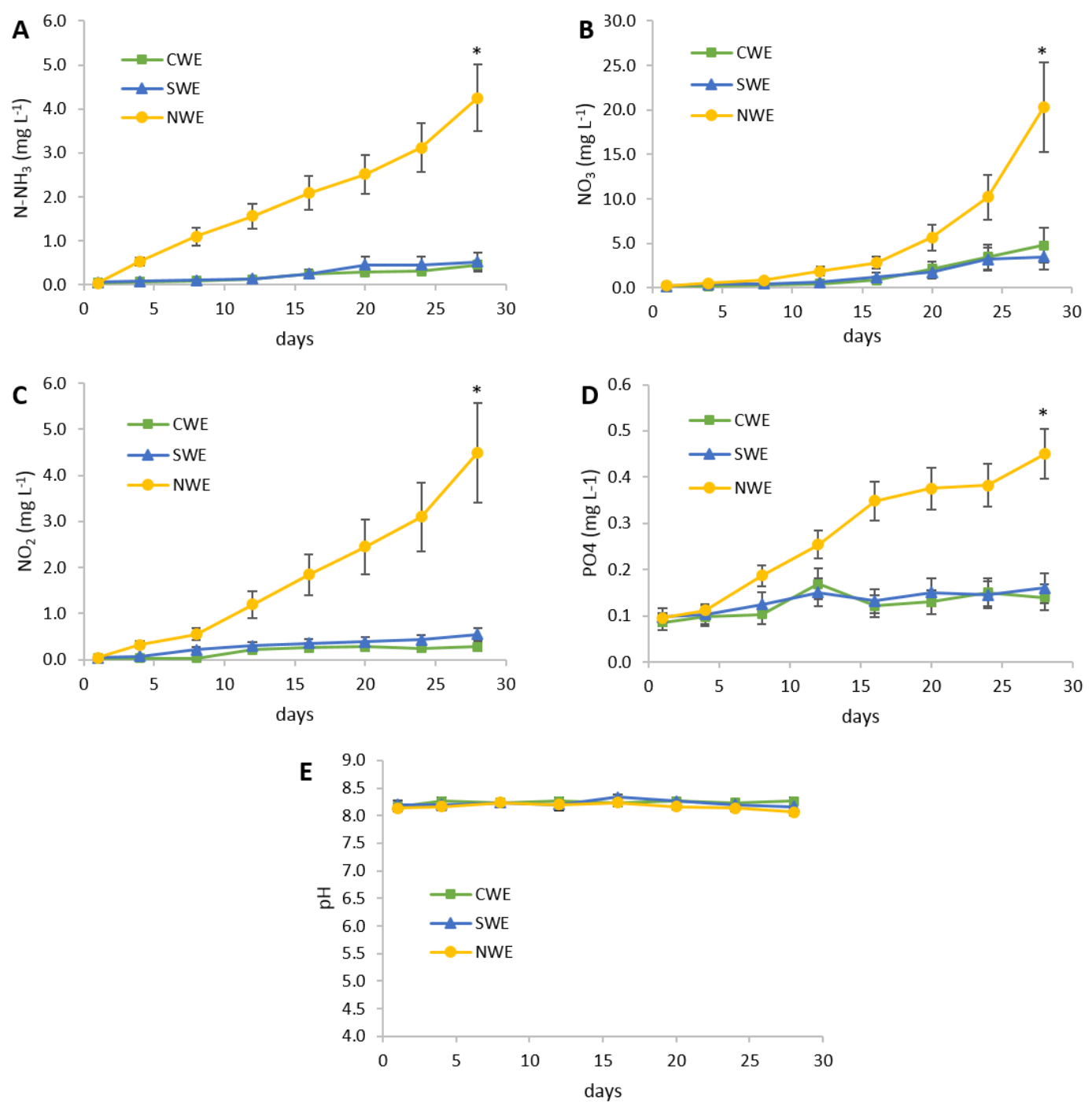

Figure 1 Water quality parameters during experiment 1 . CWE, 50\% daily clean water exchange; SWE, $50 \%$ daily exchange with water bioremediation by Ulva lactuca; NWE, no water exchange. (A) Water variations of total ammonia nitrogen $\left(\mathrm{N}-\mathrm{NH}_{3}\right)$; (B) Water variations of nitrate $\left(\mathrm{NO}_{3}\right)$; (C) Water variations of nitrite $\left(\mathrm{NO}_{2}\right)$; (D) Water variations of phosphate $\left(\mathrm{PO}_{4}\right)$; (E) Water variations of $\mathrm{pH}$. Values are given as mean \pm SD of triplicate determinations, $(*)$ are significantly different $(p<0.05)$.

Full-size DOI: 10.7717/peerj.4459/fig-1

meal resulted in $3.5 \mathrm{mg} \mathrm{g}^{-1}$ in dry basis. Results of shrimp performance after evaluation of experimental feeds with different inclusion levels of U. lactuca meal (Table 3) showed that shrimp fed diet with $3 \%$ U. lactuca meal had a significantly higher growth in terms of final weight, weight gain, and SGR $(p<0.05)$ compared to the control diet $(0 \mathrm{UL})$ and that of $1 \%$ of $U$. lactuca (1UL). Shrimp fed $2 \mathrm{UL}$ treatment showed no significant differences in growth parameters compared to the other treatments. In terms of feed utilization, the $3 \mathrm{UL}$ diet induced a significantly lower $(p<0.05)$ FCR compared to the rest of the treatments. Shrimp survival was higher than $95 \%$ in all treatments. Total lipid content in whole shrimp (Fig. 2A) was significantly higher in shrimp with $3 \mathrm{UL}$ compared to the rest of treatments 


\begin{tabular}{|c|c|c|c|c|c|}
\hline & OUL & $1 \mathrm{UL}$ & $2 \mathrm{UL}$ & $3 \mathrm{UL}$ & $P$ value \\
\hline Final weight (g) & $2.54 \pm 0.08^{\mathrm{a}}$ & $2.55 \pm 0.08^{\mathrm{a}}$ & $2.58 \pm 0.11^{\mathrm{a}, \mathrm{b}}$ & $2.78 \pm 0.06^{\mathrm{b}}$ & 0.026 \\
\hline Weight gain (\%) & $330 \pm 13^{\mathrm{a}}$ & $332 \pm 13^{\mathrm{a}}$ & $337 \pm 19^{\mathrm{a}, \mathrm{b}}$ & $371 \pm 10^{\mathrm{b}}$ & 0.028 \\
\hline SGR $\left(\%\right.$ day $\left.^{-1}\right)$ & $5.21 \pm 0.11^{\mathrm{a}}$ & $5.23 \pm 0.11^{b}$ & $5.27 \pm 0.15^{\mathrm{a}, \mathrm{b}}$ & $5.54 \pm 0.08^{b}$ & 0.030 \\
\hline FC & $2.47 \pm 0.06$ & $2.44 \pm 0.04$ & $2.51 \pm 0.06$ & $2.53 \pm 0.03$ & 0.163 \\
\hline FCR & $1.27 \pm 0.03^{b}$ & $1.25 \pm 0.05^{\mathrm{b}}$ & $1.26 \pm 0.05^{\mathrm{b}}$ & $1.15 \pm 0.03^{\mathrm{a}}$ & 0.028 \\
\hline Survival (\%) & 100 & $96 \pm 6$ & 100 & 100 & 0.441 \\
\hline
\end{tabular}

Notes.

Values are given as mean $\pm \mathrm{SD}$ of triplicate determinations. Means with different superscripts in same row are significantly different $(p<0.05)$.

$(p<0.05)$. Additionally, shrimp fed 3UL showed significantly higher concentration of total carotenoids in the head; in the muscle, 2UL and 3UL yielded significantly higher amounts of carotenoids than the rest of treatments; and considering the whole shrimp, all $U$. lactuca meal diets resulted in significantly higher content of carotenoids compared to the control diet (Fig. 2B). Lineal regression model showed a correlation between level of $U$. lactuca meal inclusion in feed and total carotenoids in whole shrimp $\left(y=3.605 x+17.22, R^{2}=0.88\right)$ and head $\left(y=5.738 x+28.518, R^{2}=0.788\right)$. Water quality parameters during the second experimental period were very stable among treatments: temperature $\left(28 \pm 0.4{ }^{\circ} \mathrm{C}\right) \mathrm{pH}$ $(8.0 \pm 0.1), \mathrm{NH} 3, \mathrm{NH} 4+\left(<0.5 \mathrm{mg} \mathrm{L}^{-1}\right), \mathrm{NO}_{2}\left(<0.25 \mathrm{mg} \mathrm{L}^{-1}\right)$, and $\mathrm{NO}_{3}\left(<5 \mathrm{mg} \mathrm{L}^{-1}\right)$.

\section{DISCUSSION}

According to the water quality parameters during experiment 1, results revealed the high efficiency of U. lactuca in removing nitrogen compounds and phosphorus from shrimp's wastewater ( $80 \%$ and $64 \%$, respectively) under the integrated recirculation system. These results are consistent with other reports describing the high efficiency of Ulvales in biofiltering inorganic compounds from aquaculture effluents. Copertino, Tormena $\&$ Seeliger (2009) determined that $U$. clathrata removes up to $70-82 \%$ of the total ammonia nitrogen (TAN) and $50 \%$ of phosphate. In a study of an intensive co-culture system of U. lactuca and L. vannamei, TAN and phosphate were significantly reduced in culture water by $25.9 \%$ and $24.6 \%$, respectively, compared to a system without $U$. lactuca (Brito et al., 2014). The nitrogenous compounds removed by seaweed reflected $15.5 \%$ protein content in meal, which revealed a higher proportion than reports in wild collected U. lactuca (7.1 to 10.7\%) (Wong \& Cheung, 2000; Yaich et al., 2011; Tabarsa et al., 2012), but lower than described for U. lactuca cultured in a controlled system (21.1\%) (Ventura $\&$ Castañón, 1998). An integration of a total or partial recirculating system of U. lactuca and shrimp may decrease the need of out coming water, improving farm biosecurity and reducing the possibility of disease outbreaks (Muniesa et al., 2015). According to the present experimental results, $U$. lactuca meets different criteria suggested by other authors to select an efficient seaweed biofilter for integrated aquaculture, which includes nutrient intake from wastewater (Kang, Park \& Chung, 2011), seaweed density, and water flow rate (Al-Hafedh, Alam \& Buschmann, 2015). 

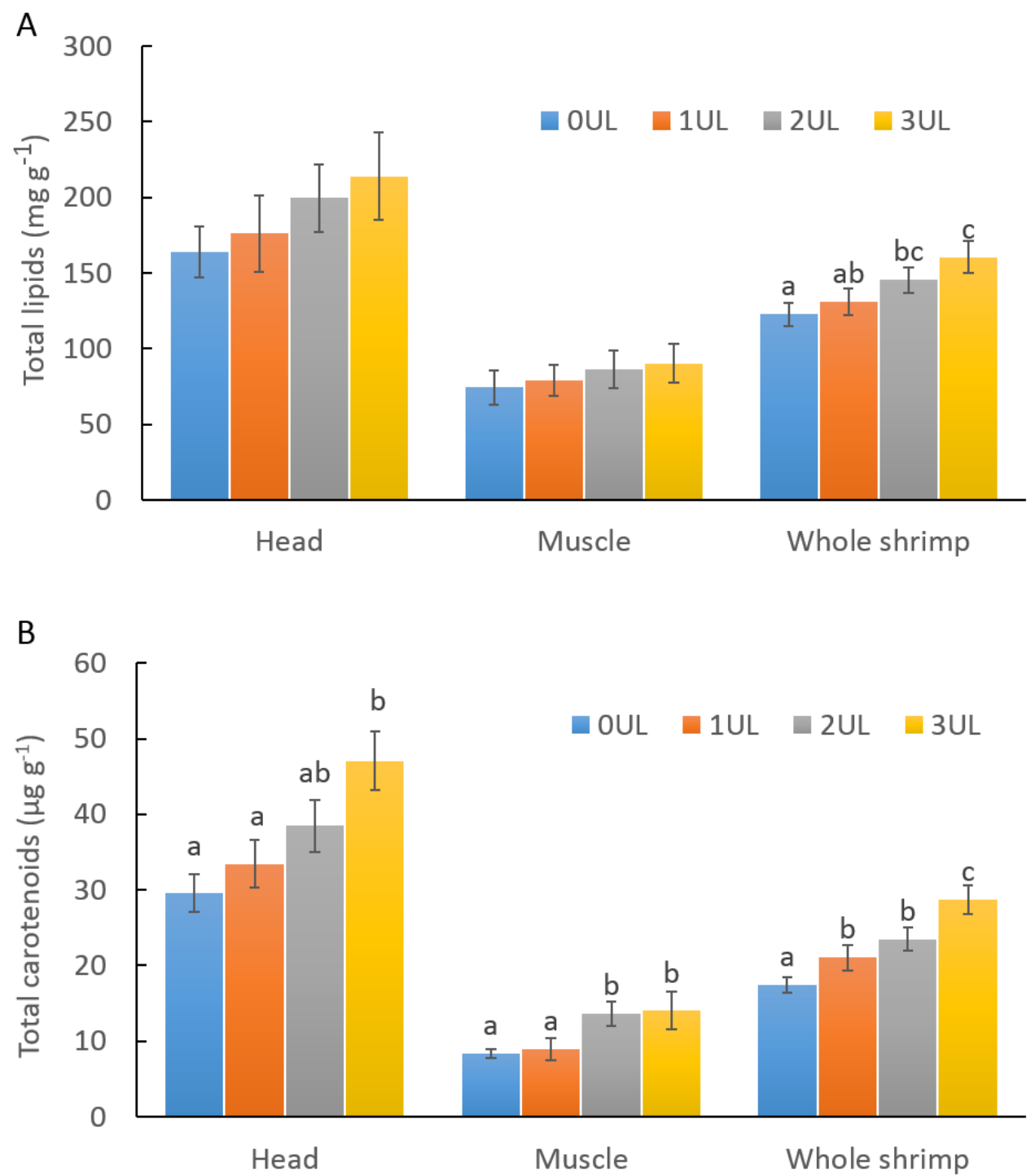

Figure 2 Total lipids and total carotenoid in shrimp fed experimental diets containing different inclusion levels of $\boldsymbol{U}$. lactuca meal. (A) Total lipids and (B) Total carotenoids in shrimp fed experimental diets containing $0 \%(0 \mathrm{UL}), 1 \%(1 \mathrm{UL}), 2 \%(2 \mathrm{UL})$ and 3\% (3UL) of $U$. lactuca meal. Values are given as mean \pm $\mathrm{SD}$ of multiple determinations $(n=5)$. Different superscripts denotes statistical differences among treatments $(p<0.05)$.

Full-size DOI: 10.7717/peerj.4459/fig-2

Water bioremediation with U. lactuca (trial 1) did not affect shrimp growth or feed utilization, as described by Fourooghifard et al. (2017), where the water quality improved without affecting shrimp growth in a zero water exchange system of integrated culture of L. vannamei and Gracilaria cortica. No significant growth differences were observed in L. vannamei cultured in floating cages with red seaweed Kappaphycus alvarezii compared to shrimp monoculture system (Lombardi et al., 2006). On the other hand, when no water exchange was performed, shrimp growth and feed utilization was affected possibly by water quality. It has been described that exposure to high concentrations of ammonia 
in water increases oxygen and energy demand in shrimp (Racotta \& Hernández-Herrera, 2000) reflected in lower growth (Chen \& Kou, 1992). However, shrimp performance in low or no water exchange culture systems can also be affected by the shrimp stock densities (Hopkins et al., 1993), feed composition (Wasielesky et al., 2006), and feeding frequency (Tacon et al., 2002).

In feeding trial 2, where U. lactuca produced by bioremediation was evaluated as feed ingredient, shrimp growth was improved when fed $3 \%$ U. lactuca meal in feed. Rodríguez-González et al. (2014) suggest that the limiting inclusion level for U. lactuca meal in shrimp feed should not exceed 5\%, showing that levels of 10 and $15 \%$ reduced significantly shrimp growth compared to a control diet without U. lactuca inclusion. Serrano Jr, Santizo \& Tumbokon (2015) also experimented with 15 and 30\% U. lactuca meal inclusion in P. monodon shrimp, finding no growth improvement at the lower inclusion level and significant reduction of shrimp growth at the higher inclusion level. Similar results in fish were observed, poor growth and feed utilization were shown in African catfish (Abdel-warith, Younis \& Al-asgah, 2016) and in Rainbow trout (Yildirim et al., 2009) when high levels of $U$. lactuca meal (>20\% and 10\% respectively) were included in feed compared with $0 \%$ inclusion, suggesting lower inclusion levels.

Shrimp growth improvement at low inclusion levels were found with other seaweed meals, as for example with 2 or 4\% of Macrocystis pyrifera (Cruz-Suárez et al., 2000) or Sargassum sp. (Suárez-García, 2006) included in shrimp feed. Yu et al. (2016) also recommends low inclusion levels (2 or 3\%) of Gracilaria lemaneiformis meal in order to improve weight gain in L. vannamei. The growth promotor effect, as in the present work, is generally attributed to vitamins, minerals and lipids present in the seaweed (Cruz-suárez et al., 2008; Tabarsa et al., 2012).

U. lactuca showed high content of ash (36.5\%) similar to the value reported by RodríguezGonzález et al. (2014) (41.7\%), which could explain the limiting inclusion level of seaweed meal in the feed. High inclusion levels of seaweed meal in feed reflects higher contents of ash, which has been related with decrement of feed digestibility (Brunson, Romaire \& Reigh, 1997; Yang et al., 2009). In a study in black tiger shrimp Penaeus monodon, apparent digestibility of $U$. lactuca meal was significantly lower (71\%) than for protein concentrate from U. lactuca (99\%) (Santizo, Serrano \& Corre, 2014). This decrement of feed digestibility on Ulva meal diets is not observed when fresh seaweed is used as food, like when shrimp are fed fresh U. lactuca (Pallaoro, do Nascimento Vieira \& Hayashi, 2016) or U. clathrata (Cruz-Suárez et al., 2010), which, in both cases, could be save at around 50\% of pelleted feed without negative effects on shrimp growth.

The increase of $30 \%$ in whole shrimp lipid content of shrimps fed $3 \%$ U. lactuca meal diet, respect to control feed, was also described in L. vannamei co-cultured with $U$. clathrata, where a combination of pelleted feed and seaweed increased up to $50 \%$ total lipid content in shrimp (Cruz-Suárez et al., 2010). This increase in shrimp lipid content could be partially attributed to carotenoids content in the algae. Carotenoid in crustaceans are responsible for pigmentation and as source of provitamin A and as antioxidants (Liñan Cabello, Paniagua-Michel \& Hopkins, 2002). Total carotenoids in the U. lactuca meal in the present study was in the range described for the same species and others Ulvales (240 
to $500 \mathrm{ug} \mathrm{g}^{-1}$ fresh weight) (Xia, Li \& Zou, 2004; Kumar et al., 2010; Peña Rodríguez et al., 2011). Shrimp fed diets with U. lactuca meal significantly increased whole shrimp carotenoid content, with the highest concentration in the head. Penaeid shrimp effectively use carotenoids from Ulvales to increase body pigmentation. Shrimp fed fresh U. clathrata increase carotenoid content as the use of pelleted food decreased (Cruz-Suárez et al., 2010). In another study, feeds with $3.3 \%$ of seaweed (U. clathrata) meal inclusion diet resulted in higher shrimp pigmentation after cooking respect to Ascophillum nodosum and Macrocystis pyrifera diets (Cruz-Suárez et al., 2009). A diet containing 5\% of Enteromorpha intestinalis meal increased significantly the astaxanthin content in $P$. monodon muscle compared to a control diet after 30 days of feeding trial (Subhra Bikash, 2015).

\section{CONCLUSIONS}

In conclusion, the results of the present study demonstrated that $U$. lactuca can be used on integrated aquaculture systems in terms of nitrogen and phosphate water bioremediation, and the inclusion of the seaweed biomass produced as feed additive improves shrimp growth performance and shrimp carotenoid content.

\section{ACKNOWLEDGEMENTS}

We thank Gustavo Pineda from Acuacultura Mahr, SA de CV for kindly donating the shrimp juveniles, and Sandra de la Paz-Reyes from Laboratory of Aquaculture Nutrition and also Pablo Monsalvo-Spencer and Gabriel Robles Villegas from the laboratory for acclimatization and maintenance of aquatic organisms at CIBNOR for all the facilities and technical support during the experiment.

\section{ADDITIONAL INFORMATION AND DECLARATIONS}

\section{Funding}

This work was supported by Consejo Nacional de Ciencia y Tecnología (CONACYT) México (Project No. 2015-01-1680). The funders had no role in study design, data collection and analysis, decision to publish, or preparation of the manuscript.

\section{Grant Disclosures}

The following grant information was disclosed by the authors:

Consejo Nacional de Ciencia y Tecnología (CONACYT) México: 2015-01-1680.

\section{Competing Interests}

The authors declare there are no competing interests.

\section{Author Contributions}

- Regina Elizondo-González conceived and designed the experiments, performed the experiments, analyzed the data, prepared figures and/or tables, authored or reviewed drafts of the paper, approved the final draft. 
- Eduardo Quiroz-Guzmán performed the experiments, contributed reagents/materials/analysis tools, authored or reviewed drafts of the paper, approved the final draft.

- Cristina Escobedo-Fregoso conceived and designed the experiments, analyzed the data, contributed reagents/materials/analysis tools, authored or reviewed drafts of the paper, approved the final draft.

- Paola Magallón-Servín analyzed the data, prepared figures and/or tables, authored or reviewed drafts of the paper, approved the final draft.

- Alberto Peña-Rodríguez conceived and designed the experiments, performed the experiments, analyzed the data, contributed reagents/materials/analysis tools, prepared figures and/or tables, authored or reviewed drafts of the paper, approved the final draft.

\section{Field Study Permissions}

The following information was supplied relating to field study approvals (i.e., approving body and any reference numbers):

Wild collection of native Ulva sp. (sea lettuce) was approved by the Secretary of Agriculture, Animal breeding, Rural development, Fisheries and Food (Secretaria de Agricultura, Ganadería, Desarrollo Rural, Pesca y Alimentación) CONAPESCA, México (\#PRMN/DGOPA-019/2015).

\section{Data Availability}

The following information was supplied regarding data availability:

The raw data generated from experimental trials and chemical analysis are provided as a Supplemental File.

\section{Supplemental Information}

Supplemental information for this article can be found online at http://dx.doi.org/10.7717/ peerj.4459\#supplemental-information.

\section{REFERENCES}

Abdel-warith AA, Younis EMI, Al-asgah NA. 2016. Potential use of green macroalgae Ulva lactuca as a feed supplement in diets on growth performance, feed utilization and body composition of the African catfish, Clarias gariepinus. Saudi Journal of Biological Sciences 23:404-409 DOI 10.1016/j.sjbs.2015.11.010.

Al-Hafedh YS, Alam A, Buschmann AH. 2015. Bioremediation potential, growth and biomass yield of the green seaweed, Ulva lactuca in an integrated marine aquaculture system at the Red Sea coast of Saudi Arabia at different stocking densities and effluent flow rates. Reviews in Aquaculture 7:161-171 DOI 10.1111/raq.12060.

Barnes H, Blackstock J. 1973. Estimation of lipids in marine animals and tissues: detailed investigation of the sulphophosphovanilun method for "total" lipids. Journal of Experimental Marine Biology and Ecology 12:103-118 DOI 10.1016/0022-0981(73)90040-3. 
Brito LO, Arantes R, Magnotti C, Derner R, Pchara F, Olivera A, Vinatea L. 2014. Water quality and growth of Pacific white shrimp Litopenaeus vannamei (Boone) in coculture with green seaweed Ulva lactuca (Linaeus) in intensive system. Aquaculture International 22:497-508 DOI 10.1007/s10499-013-9659-0.

Brunson JF, Romaire RP, Reigh RC. 1997. Apparent digestibility of selected ingredients in diets for white shrimp Penaeus setiferus L. Aquaculture Nutrition 3:9-16 DOI 10.1046/j.1365-2095.1997.00068.x.

Cárdenas JV, Gálvez AO, Brito LO, Galarza EV, Pitta DC, Rubin VV. 2015. Assessment of different levels of green and brown seaweed meal in experimental diets for whiteleg shrimp (Litopenaeus vannamei, Boone) in recirculating aquaculture system. Aquaculture International 23:1491-1504 DOI 10.1007/s10499-015-9899-2.

Casas-Valdez M, Portillo-Clark G, Aguila-Ramírez N, Rodríguez-Astudillo S, SánchezRodríguez I, Carrillo-Domínguez S. 2006. Efecto del alga marina Sargassum spp sobre las variables productivas y la concentración de colesterol en el camarón café, Farfantepenaeus californiensis (Holmes, 1900). Revista de Biologia Marina y Oceanografia 41:97-105.

Chen JC, Kou YZ. 1992. Effects of ammonia on growth and molting of Penaeus japonicus juveniles. Aquaculture 104:249-260 DOI 10.1016/0044-8486(92)90207-2.

Copertino MS, Tormena T, Seeliger U. 2009. Biofiltering efficiency, uptake and assimilation rates of Ulva clathrata (Roth) J. Agardh (Clorophyceae) cultivated in shrimp aquaculture waste water. Journal of Applied Phycology 21:31-45 DOI 10.1007/s10811-008-9357-x.

Cruz-Suárez LE, León A, Peña-Rodríguez A, Rodríguez-Peña G, Moll B, RicqueMarie D. 2010. Shrimp/Ulva co-culture: a sustainable alternative to diminish the need for artificial feed and improve shrimp quality. Aquaculture 301:64-68 DOI 10.1016/j.aquaculture.2010.01.021.

Cruz-Suárez LE, Ricque-Marie D, Tapia-Salazar M, Guajardo-Barbosa C. 2000. Uso de harina de kelp (Macrocystis pyrifera) en alimentos para camarón. In: Cruz-Suárez LE, Ricque-Marie D, Tapia-Salazar M, Olvera-Novoa MA, Cerecedo-Olvera R, eds. Avances en Nutrición Acuícola V. Memorias del Quinto Simposium Internacional de Nutrición Acuícola. Monterrey: Universidad Autónoma de Nuevo León, 227-266.

Cruz-Suárez LE, Tapia-Salazar M, Nieto-López MG, Guajardo-Barbosa C, RicqueMarie D. 2009. Comparison of Ulva clathrata and the kelps Macrocystis pyrifera and Ascophyllum nodosum as ingredients in shrimp feeds. Aquaculture Nutrition 15:421-430 DOI 10.1111/j.1365-2095.2008.00607.x.

Cruz-suárez LE, Tapia-salazar M, Nieto-López MG, Ricque-marie D. 2008. A review of the effects of macroalgae in shrimp feeds and in co-culture. In: Cruz-suárez LE, Ricque-marie D, Tapia-salazar M, eds. Avances en Nutrición Acuicola IX. San Nicolás de los Garza: Universidad Autónoma de Nuevo León, 304-333.

Da Silva RL, Barbosa JM. 2009. Seaweed meal as a protein source for the white shrimp Litopenaeus vannamei. Journal of Applied Phycology 21:193-197 DOI 10.1007/s10811-008-9350-4. 
DeBusk TA, Blakeslee M, Ryther JH. 1986. Studies on the outdorr cultivation of Ulva lactuca L. Botanica Marina 29(4):381-386 DOI 10.1515/botm.1986.29.5.381.

FAO (Food and Agriculture Organization of the United Nations). 2017. Fishery and aquaculture statistics. Global production by production source, 1950-2015 (FishStatJ). Updated 2017. FAO Fisheries and Aquaculture Department. FAO, Rome, Italy. Available at http://www.fao.org/fishery/statistics/global-aquacultureproduction/query/es (accessed on 18 April 2017).

Fleurence J, Morançais M, Dumay J, Decottignies P, Turpin V, Munier M, GarcíaBueno N, Jaouen P. 2012. What are the prospects for using seaweed in human nutrition and for marine animals raised through aquaculture?

Trends in Food Science and Technology 27:57-61 DOI 10.1016/j.tifs.2012.03.004.

Fourooghifard H, Matinfar A, Mortazavi MS, Roohani Ghadikolaee K, Mirbakhsh M. 2017. Growth parameters of whiteleg shrimp Litopenaeus vannamei and red seaweed Gracilaria corticata in integrated culturing method under zero water exchange system. Aquaculture Research 48:5235-5242 DOI 10.1111/are.13335.

Herbeck LS, Unger D, Wu Y, Jennerjahn TC. 2013. Effluent, nutrient and organic matter export from shrimp and fish ponds causing eutrophication in coastal and backreef waters of NE hainan, tropical China. Continental Shelf Research 57:92-104 DOI 10.1016/j.csr.2012.05.006.

Hopkins JS, Hamilton RD, Sandier PA, Browdy CL, Stokes AD. 1993. Effect of water exchange rate on production, water quality, effluent characteristics and nitrogen budgets of intensive shrimp ponds. Journal of the World Aquaculture Society 24:304-320 DOI 10.1111/j.1749-7345.1993.tb00162.x.

Kang YH, Park SR, Chung IK. 2011. Biofiltration efficiency and biochemical composition of three seaweed species cultivated in a fish-seaweed integrated culture. Algae 26:97-108 DOI 10.4490/algae.2011.26.1.097.

Kumar M, Gupta V, Kumari P, Reddy CRK, Jha B. 2011. Assessment of nutrient composition and antioxidant potential of Caulerpaceae seaweeds. Journal of Food Composition and Analysis 24:270-278 DOI 10.1016/j.jfca.2010.07.007.

Kumar M, Kumari P, Gupta V, Anisha PA, Reddy CRK, Jha B. 2010. Differential responses to cadmium induced oxidative stress in marine macroalga Ulva lactuca (Ulvales, Chlorophyta). Biometals 23:315-325 DOI 10.1007/s10534-010-9290-8.

Liñan Cabello MA, Paniagua-Michel J, Hopkins PM. 2002. Bioactive roles of carotenoids and retinoids in crustaceans. Aquaculture Nutrition 8:299-309 DOI 10.1046/j.1365-2095.2002.00221.x.

Little DC, Newton RW, Beveridge MCM. 2016. Aquaculture: a rapidly growing and significant source of sustainable food? Status, transitions and potential. Proceedings of the Nutrition Society 75:274-286 DOI 10.1017/S0029665116000665.

Lombardi JV, Marques HLD, Pereira RTL, Barreto OJS, Paula EJ. 2006. Cage polyculture of the Pacific white shrimp Litopenaeus vannamei and the Philippines seaweed Kappaphycus alvarezii. Aquaculture 258:412-415

DOI 10.1016/j.aquaculture.2006.04.022. 
Marinho-Soriano E, Camara MR, Cabral TD, Carneiro MAD. 2007. Preliminary evaluation of the seaweed Gracilaria cervicornis (Rhodophyta) as a partial substitute for the industrial feeds used in shrimp (Litopenaeus vannamei) farming. Aquaculture Research 38:182-187 DOI 10.1111/j.1365-2109.2006.01646.x.

Muniesa A, Perez-Enriquez R, Cabanillas-Ramos J, Magallón-Barajas FJ, ChávezSánchez C, Esparza-Leal H, Blas I. 2015. Identifying risk factors associated with White Spot Disease outbreaks of shrimps in the Gulf of California (Mexico) through expert opinion and surveys. Reviews in Aquaculture 9:257-265 DOI 10.1111/raq.12136.

Neori A. 2008. Essential role of seaweed cultivation in integrated multi-trophic aquaculture farms for global expansion of mariculture: an analysis. Journal of Applied Phycology 20:567-570 DOI 10.1007/s10811-007-9206-3.

Neori A, Chopin T, Troell M, Buschmann AH, Kraemer GP, Halling C, Shpigel M, Yarish CH. 2004. Integrated aquaculture: rationale, evolution and state of the art emphasizing seaweed biofiltration in modem mariculture. Aquaculture 231:361-391 DOI 10.1016/j.aquaculture.2003.11.015.

Ortiz J, Romero N, Robert P, Araya J, Lopez-Hernández J, Bozzo C, Navarrete E, Osorio A, Rios A. 2006. Dietary fiber, amino acid, fatty acid and tocopherol contents of the edible seaweeds Ulva lactuca and Durvillaea antarctica. Food Chemistry 99:98-104 DOI 10.1016/j.foodchem.2005.07.027.

Palacios E, Ramirez JL, Ibarra AM, Racotta IS. 1999. Reproductive exhaustion in shrimp (Penaeus vannamei) reflected in larval biochemical composition, survival and growth. Aquaculture 171:309-321 DOI 10.1016/S0044-8486(98)00393-7.

Pallaoro MF, do Nascimento Vieira F, Hayashi L. 2016. Ulva lactuca (Chlorophyta Ulvales) as co-feed for Pacific white shrimp. Journal of Applied Phycology 28:3659-3665 DOI 10.1007/s10811-016-0843-2.

Peña Rodríguez A, Elizondo-González R, Nieto-López MG, Ricque-Marie D, CruzSuárez LE. 2017. Practical diets for the sustainable production of brown shrimp, Farfantepenaeus californiensis, juveniles in presence of the green macroalga Ulva clathrata as natural food. Journal of Applied Phycology 29:413-421 DOI 10.1007/s10811-016-0846-z.

Peña Rodríguez A, Magallón-Barajas FJ, Cruz-Suárez LE, Elizondo-González R, Moll B. 2016. Effects of stocking density on the performance of brown shrimp Farfantepenaeus californiensis co-cultured with the green seaweed Ulva clathrata. Aquaculture Research 48:2803-2811 DOI 10.1111/are.13114.

Peña Rodríguez A, Mawhinney TP, Ricque-Marie D, Cruz-Suárez LE. 2011. Chemical composition of cultivated seaweed Ulva clathrata (Roth) C. Agardh. Food Chemistry 129:491-498 DOI 10.1016/j.foodchem.2011.04.104.

Portillo-Clark G, Casillas-Hernandez R, Servin-Villegas R, Magallon-Barajas FJ. 2012. Growth and survival of the juvenile yellowleg shrimp Farfantepenaeus californiensis cohabiting with the green feather alga Caulerpa sertularioides at different temperatures. Aquaculture Research 44:22-30 DOI 10.1111/j.1365-2109.2011.03002.x. 
Racotta IS, Hernández-Herrera R. 2000. Metabolic responses of the white shrimp, Penaeus vannamei, to ambient ammonia. Comparative Biochemistry and PhysiologyPart A: Molecular \& Integrative Physiology 125:437-443

DOI 10.1016/S1095-6433(00)00171-9.

Rodríguez-González H, Orduña-Rojas J, Villalobos-Medina JP, García-Ulloa M, Polanco-Torres A, López-Álvarez ES, Montoya-Mejía M, Hernández-Llamas A. 2014. Partial inclusion of Ulva lactuca and Gracilaria parvispora meal in balanced diets for white leg shrimp (Litopenaeus vannamei). Journal of Applied Phycology 26:2453-2459 DOI 10.1007/s10811-014-0272-z.

Santizo RB, Serrano Jr AE, Corre VL. 2014. Proximate composition and dry matter digestibility of Ulva lactuca in the black tiger shrimp Penaeus monodon. ABAH Bioflux 6:75-83.

Schleder DD, Da Rosa JR, Guimarães AM, Ramlov F, Maraschin M, Seiffert WQ, Vieira FN, Hayashi L, Andreatta ER. 2017. Brown seaweeds as feed additive for white-leg shrimp: effects on thermal stress resistance, midgut microbiology, and immunology. Journal of Applied Phycology 29:2471-2477 DOI 10.1007/s10811-017-1129-z.

Serrano Jr AE, Santizo RB, Tumbokon BLM. 2015. Potential use of the sea lettuce Ulva lactuca replacing soybean meal in the diet of the black tiger shrimp Penaeus monodon juvenile. International Journal of the Bioflux Society 8:245-252.

Suárez-García HA. 2006. Efecto de la inclusión de alginato y harina de algas Sargassum sp. y Macrocistys pyrifera sobre la estabilidad en agua, digestibilidad del alimento y sobre el crecimiento del camarón blanco Litopenaeus vannamei. Undergrate thesis, Universidad Autonóma de Nuevo León, Mexico.

Subhra Bikash KM. 2015. Seaweed incorporated diet improves astaxanthin content of shrimp muscle tissue. Journal of Marine Science: Research and Development 5:8-11 DOI 10.4172/2155-9910.1000161.

Syad AN, Shunmugiah KP, Kasi PD. 2013. Seaweeds as nutritional supplements: analysis of nutritional profile, physicochemical properties and proximate composition of G. Acerosa and S. Wightii. Biomedicine \& Preventive Nutrition 3:139-144 DOI 10.1016/j.bionut.2012.12.002.

Tabarsa M, Rezaei M, Ramezanpour Z, Waaland JR. 2012. Chemical compositions of the marine algae Gracilaria salicornia (Rhodophyta) and Ulva lactuca (Chlorophyta) as a potential food source. Journal of the Science of Food and Agriculture 92:2500-2506 DOI 10.1002/jsfa.5659.

Tacon AGJ, Cody JJ, Conquest LD, Divakaran S, Forster IP, Decamp OE. 2002. Effect of culture system on the nutrition and growth performance of Pacific white shrimp Litopenaeus vannamei (Boone) fed different diets. Aquaculture Nutrition 8:121-137 DOI 10.1046/j.1365-2095.2002.00199.x.

Van Khoi L, Fotedar R. 2011. Integration of western king prawn (Penaeus latisulcatus Kishinouye, 1896) and green seaweed (Ulva lactuca Linnaeus, 1753) in a closed recirculating aquaculture system. Aquaculture 322-323:201-209 DOI 10.1016/j.aquaculture.2011.09.030. 
Ventura MR, Castañón JIR. 1998. The nutritive value of seaweed (Ulva lactuca) for goats. Small Ruminant Research 29:325-327 DOI 10.1016/s0921-4488(97)00134-x.

Wasielesky W, Atwood H, Stokes A, Browdy CL. 2006. Effect of natural production in a zero exchange suspended microbial floc based super-intensive culture system for white shrimp Litopenaeus vannamei. Aquaculture 258:396-403 DOI 10.1016/j.aquaculture.2006.04.030.

Wong KH, Cheung PCK. 2000. Nutritional evaluation of some subtropical red and green seaweeds: part I-proximate composition, amino acid profiles and some physicochemical properties. Food Chemistry 71:475-482

DOI 10.1016/s0308-8146(00)00175-8.

Xia J, Li Y, Zou D. 2004. Effects of salinity stress on PSII in Ulva lactuca as probed by chlorophyll fluorescence measurements. Aquatic Botany 80:129-137 DOI 10.1016/j.aquabot.2004.07.006.

Yaich H, Garna H, Besbes S, Paquot M, Blecker C, Attia H. 2011. Chemical composition and functional properties of Ulva lactuca seaweed collected in Tunisia. Food Chemistry 128:895-901 DOI 10.1016/j.foodchem.2011.03.114.

Yang Q, Zhou X, Zhou Q, Tan B, Chi S, Dong X. 2009. Apparent digestibility of selected feed ingredients for white shrimp Litopenaeus vannamei, Boone. Aquaculture Research 41:78-86 DOI 10.1111/j.1365-2109.2009.02307.x.

Yildirim Ö, Ergun S, Yaman S, Turker A. 2009. Effects of two seaweeds (Ulva lactuca and Enteromorpha linza) as a feed additive in diets on growth performance, feed utilization, and body composition of rainbow trout (Oncorhynchus mykiss). Kafkas Universitesi Veteriner Fakultesi Dergisi 15:455-460.

Yu YY, Chen WD, Liu YJ, Niu J, Chen M, Tian LX. 2016. Effect of different dietary levels of Gracilaria lemaneiformis dry power on growth performance, hematological parameters and intestinal structure of juvenile Pacific white shrimp (Litopenaeus vannamei). Aquaculture 450:356-362 DOI 10.1016/j.aquaculture.2015.07.037. 